3. Petrof BJ. The molecular basis of activity-induced muscle injury in Duchenne muscular dystrophy. Mol Cell Biochem 1998;179:111-123.

4. Johnson EW, Braddom R. Over-work weakness in facioscapulohumeral muscular dystrophy. Arch Phys Med Rehabil 1971;52:333-336.

5. Aitkens SG, McCrory MA, Kilmer DD, Bernauer EM. Moderate resistance exercise program: its effect in slowly progressive neuromuscular disease. Arch Phys Med Rehabil 1993;74:711-715.

6. Florence JM, Hagberg JM. Effect of training on the exercise responses of neuromuscular disease patients. Med Sci Sports Exercise 1984;16: $460-465$.
7. Tawil R, Figlewicz DA, Griggs RC, Weiffenbach B. Fascioscapulohumeral dystrophy: a distinct regional myopathy with a novel molecular pathogenesis. FSH consortium. Ann Neurol 1998;43:279-282.

8. Rowell LB, Saltin B, Kiens B, Christensen NJ. Is peak quadriceps blood flow in human even higher during exercise with hypoxemia? Am J Physiol 1986;251:1038-1044.

9. Holloszy JO, Coyle EF. Adaptations of skeletal muscle to endurance exercise and their metabolic consequences. J Appl Physiol 1984;56:831-838.

10. Hardiman O. Dystrophin deficiency, altered cell signaling and fibre hypertrophy. Neuromusc Disord 1994;4:305-315.

\title{
Neurolmages
}
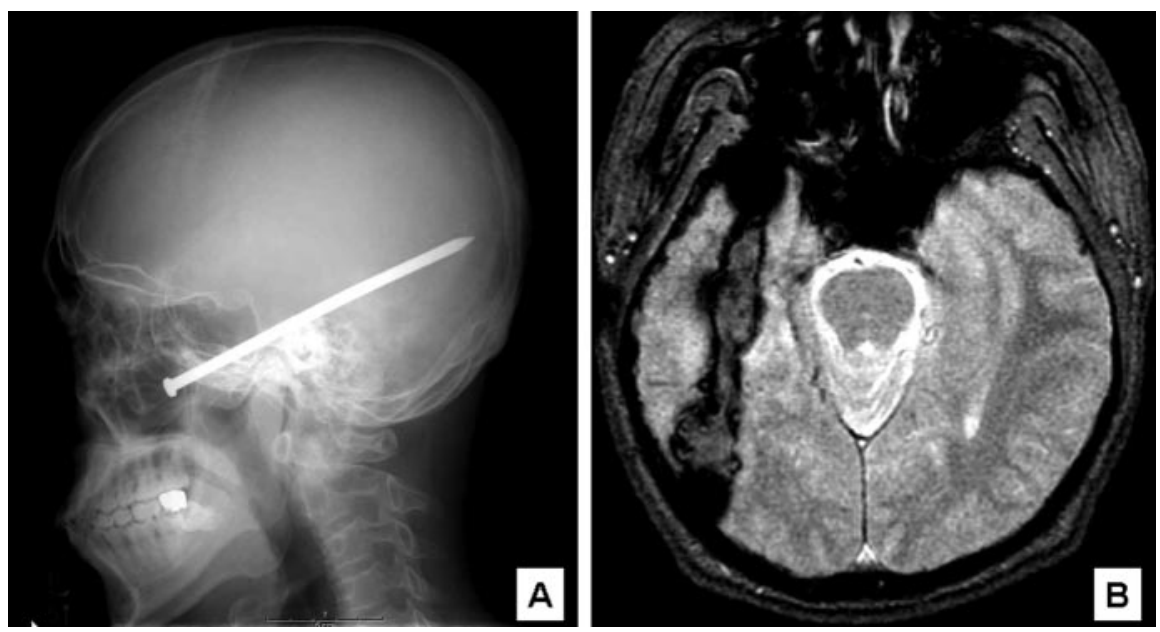

Figure. (A) Preoperative lateral plain skull $x$-ray shows the nail. (B) Postoperative angulated axial gradient-echo $M R I$ reveals hemorrhagic tract.

\section{FIGH \\ Missing nail for 22 years}

Dae Won Seo, MD, PhD; and

Gregory Youngnam Chang, LTC, MC, Seoul, Korea

Note: The opinions or assertions contained herein are the private views of the author (G.Y.C.) and are not to be construed as representing the views of the Department of Defense, or the Department of the Army.

Address correspondence and reprint requests to Dr. Gregory Youngnam Chang, HHC 121st US Army Gen Hosp, Box \#277, APO AP 96205-0017, USA; e-mail: gychang@operamail.com
A 31-year-old man had a 2-year history of stereotyped seizures characterized by a sudden falling sensation followed by motionless stare or with a sudden loss of consciousness without an aura, occurring once weekly. When he was 9 , he misfired a homemade wooden nail gun. Upon regaining consciousness minutes later, his right cheek was sore and swollen and there was a trace of blood. $\mathrm{He}$ and his older brother were perplexed because they could not find the nail.

He denied any neurologic symptoms and examination disclosed no focal abnormality. An EEG revealed right temporal slowing. Without a proper screening, a brain MRI was attempted and was quickly terminated due to onset of a severe headache. A skull film revealed the cause (figure). After removal of the nail via the maxillary sinus, he had a flurry of seizures. Seizure frequency improved to one seizure every 3 months on Tegretol.

Copyright $\odot 2005$ by AAN Enterprises, Inc. 


\title{
Neurology
}

\author{
Missing nail for 22 years \\ Dae Won Seo and Gregory Youngnam Chang \\ Neurology 2005;64;1066 \\ DOI 10.1212/WNL.64.6.1066
}

This information is current as of March 21, 2005

\section{Updated Information \&} Services

Supplementary Material

Permissions \& Licensing

Reprints including high resolution figures, can be found at: http://n.neurology.org/content/64/6/1066.full

Supplementary material can be found at: http://n.neurology.org/content/suppl/2007/04/02/64.6.1066.DC1

Information about reproducing this article in parts (figures,tables) or in its entirety can be found online at:

http://www.neurology.org/about/about_the_journal\#permissions

Information about ordering reprints can be found online: http://n.neurology.org/subscribers/advertise

Neurology ${ }^{\circledR}$ is the official journal of the American Academy of Neurology. Published continuously since 1951, it is now a weekly with 48 issues per year. Copyright . All rights reserved. Print ISSN: 0028-3878. Online ISSN: 1526-632X.

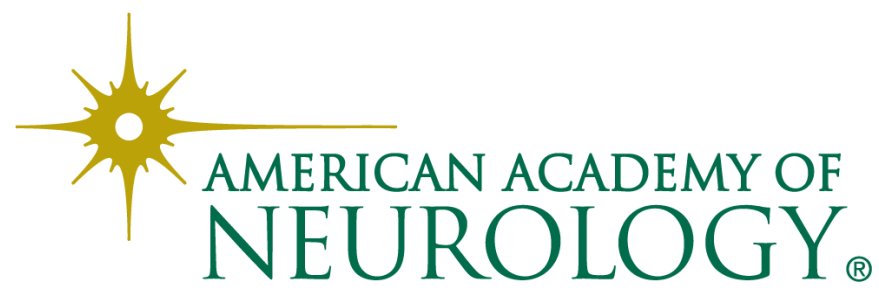

